\title{
On Powellithecidae fam. nov., a new Pliocene to Recent bryozoan family endemic to New Zealand, with the description of Powellitheca gen. nov. (Bryozoa, Cheilostomata)
}

\author{
Emanuela DI MARTINO ${ }^{1, *}$, Paul D. TAYLOR ${ }^{2}$, Dennis P. GORDON ${ }^{3}$ \& Lee Hsiang LIOW ${ }^{4,5}$ \\ ${ }^{1,2}$ Department of Earth Sciences, Natural History Museum, Cromwell Road, London SW7 5BD, UK. \\ ${ }^{3}$ National Institute of Water and Atmospheric Research (NIWA), Wellington, New Zealand. \\ ${ }^{4}$ Centre for Ecological and Evolutionary Synthesis, Department of Biosciences, \\ University of Oslo, Oslo, Norway. \\ ${ }^{5}$ Natural History Museum, University of Oslo, Oslo, Norway \\ ${ }^{*}$ Corresponding author: e.di-martino@nhm.ac.uk \\ ${ }^{2}$ Email: p.taylor@nhm.ac.uk \\ ${ }^{3}$ Email: dennis.gordon@niwa.co.uk \\ ${ }^{4}$ Email: 1.h.liow@ibv.uio.no \\ ${ }^{1}$ urn:lsid:zoobank.org:author:A7905C48-FF37-4D27-BCCE-F0560AF040A2 \\ ${ }^{2}$ urn:1sid:zoobank.org:author:7AFF2929-DF5B-46B2-94E6-B26B396CC2C8 \\ ${ }^{3}$ urn:1sid:zoobank.org:author:DD9C0F3A-8512-4AC8-B395-7687CE3FC565 \\ ${ }^{4}$ urn:Isid:zoobank.org:author:9A708FAA-486A-4918-AAC9-AF7795F3B675
}

\begin{abstract}
A new cheilostome bryozoan genus, Powellitheca gen. nov., is erected here for three species from New Zealand, one of which has been previously assigned to Emballotheca Levinsen, 1909, but which differ significantly from the Australian type species of Emballotheca, E. quadrata (MacGillivray, 1880). Notably, whereas Emballotheca has a cormidial orifice (i.e., formed by numerous neighbouring zooids), and lepralielliform ooecia, the orifice of Powellitheca gen. nov. is formed by single zooids and ooecia are of the microporelliform type. The introduction of a new family, Powellithecidae fam. nov., becomes necessary because of the nonconformity of Powellitheca gen. nov. with other known families having microporelliform ooecia. In addition to the Recent type species Powellitheca terranovae gen. et sp. nov., one other new Recent species, P. labiosa gen. et sp. nov., and a Plio-Pleistocene fossil species, Monoporella waipukurensis Waters, 1887, are assigned to the new genus.
\end{abstract}

Keywords. Cheilostomata, Powellithecidae, Plio-Pleistocene, Recent, Wanganui Basin.

Di Martino E., Taylor P.D., Gordon D.P. \& Liow L.H. 2016. On Powellithecidae fam. nov., a new Pliocene to Recent bryozoan family endemic to New Zealand, with the description of Powellitheca gen. nov. (Bryozoa, Cheilostomata). European Journal of Taxonomy 207: 1-17. http://dx.doi.org/10.5852/ejt.2016.207

\section{Introduction}

Since its first description by Waters (1887) as Monoporella waipukurensis Waters, 1887, the common New Zealand Plio-Pleistocene species currently known as Emballotheca waipukurensis has caused 
problems for taxonomists, who have placed it in various genera, always with a degree of uncertainty. Brown (1952) excluded the species from Monoporella Hincks, 1881, as defined by Harmer (1926), but had difficulties in choosing an alternative genus, thus assigning it to "Hippoporina?" Neviani, 1895, pending the availability of better material to confirm his identification. Powell (1967) found, for the first time, several infertile specimens of what seemed to be the same species in Recent material obtained by the 'Terra Nova' Expedition in 1910. He discussed Brown's tentative assignment of M. waipukurensis to Hippoporina, noting that the dimorphic orifices, gigantic ooecia and randomly occurring lateral avicularia were features associated with Emballotheca Levinsen, 1909. Although Powell noted that the New Zealand species was clearly related to the Australian type species of Emballotheca, E. quadrata (MacGillivray, 1880), he observed some significant differences between the two taxa in the development of condyles and the arrangement of avicularia on the fertile zooids, as well as discrepancies among fossil and modern specimens with regards to the presence/absence of the lyrula and suboral mucro and in the size of colonies.

Images obtained by Scanning Electron Microscopy (SEM) of a Recent specimen of Emballotheca quadrata in the Zoological Collection of the Natural History Museum, London (NHMUK) have allowed us to investigate further the differences between E. quadrata and ostensibly congeneric species from New Zealand, leading to the introduction of the new genus, Powellitheca gen. nov., for the New Zealand species. Furthermore, comparison of SEM images of fossil and present-day specimens assigned to E. waipukurensis confirm the morphological differences first pointed out by Powell (1967). We consider the dissimilarity to be sufficient to justify the proposal of a new species for Recent material, P. terranovae gen. et sp. nov., which is chosen as the type species of Powellitheca gen. nov. A second new Recent species of Powellitheca gen. nov., P. labiosa gen. et sp. nov., is described from northern New Zealand. As Powellitheca gen. nov. does not conform to any of the other five families with microporelliform ooecial structure, the new family Powellithecidae fam. nov. is also introduced here.

\section{Material and methods}

This study is based on both fossil and Recent material from New Zealand. Fossil specimens of Powellitheca waipukurensis comb. nov. were collected from the Pleistocene Nukumaru Limestone by one of us (PDT) in March 1996 at Waiinu Beach, west of Wanganui in the North Island of New Zealand. Recent material of P. terranovae gen. et sp. nov. was collected on 2 Dec. 1981, using a rock dredge in Stephens Hole, Cook Strait, at NIWA's New Zealand Oceanographic Institute (NZOI) Station Q686 $\left(40^{\circ} 41.3^{\prime} \mathrm{S}, 174^{\circ} 03.8^{\prime} \mathrm{E}\right)$, at a depth of $205 \mathrm{~m}$. Both fossil and Recent colonies are commonly found encrusting mollusc or brachiopod shells. Four specimens of the new species P. labiosa gen. et sp. nov. were collected on 29 Mar. 2011 by epibenthic sled, South Maria ridge, NE of Three Kings Islands, at

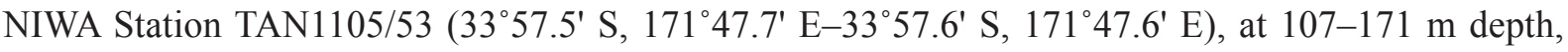
as an epibiont of the erect cheilostome bryozoan Malakosaria sinclairii (Busk, 1857), partly wrapping around the host branch.

The fossil specimens used in this study are deposited in the palaeontological collections of the NHMUK, while the Recent ones are housed in the NIWA Invertebrate Collection of the National Institute of Water and Atmospheric Research in Wellington.

For further comparison, a Recent specimen of Emballotheca quadrata (NHMUK 1897.5.1.830) from Port Phillip Heads (Victoria, Australia) and the lectotype, chosen by Brown (1952), of P. waipukurensis comb. nov. (NHMUK D32522) from Waipukurau Gorge (?Pliocene), housed in the zoological and in the palaeontological collections of NHMUK, respectively, were also examined, as was contemporaneous material (15 colonies) from Hatuma Quarry, near Waipukurau, housed in the NIWA Invertebrate Collection (NIWA 98228). 
Uncoated specimens were studied and imaged using a LEO 1455VP SEM at the NHMUK and a Hitachi TM3000 Tabletop SEM at NIWA. Linear measurements were made using optical eyepiece micrometers and from SEM images using the image processing ImageJ. They are given as the total number of measurements made $(\mathrm{N})$, mean in microns plus/minus standard deviation (SD), and observed range (Min and Max).

\section{Measurements are abbreviated as such:}

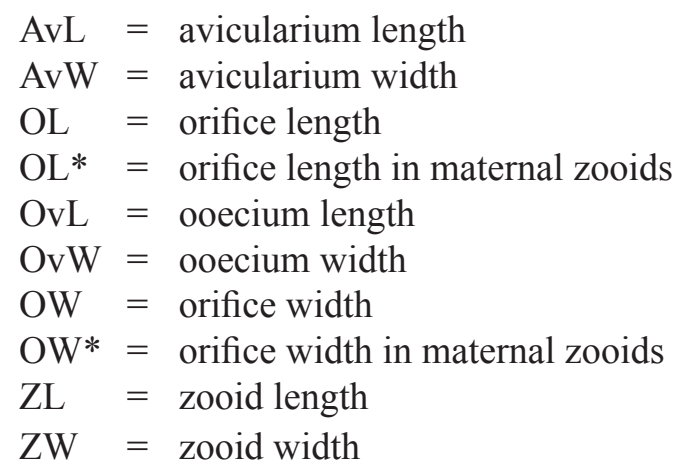

\section{Results}

Order Cheilostomata Busk, 1852

Superfamily Smittinoidea Levinsen, 1909

Family Powellithecidae fam. nov. urn:1sid:zoobank.org:act:F43BC913-D3B4-457A-A73C-2B4A5F0897AC

\section{Type genus}

Powellitheca gen. nov.

\section{Diagnosis}

See genus diagnosis below.

\section{Remarks}

Powellithecidae fam. nov. is erected to accommodate the new genus Powellitheca gen. nov., characterised by a unique suite of morphological characters when compared with all the known families sharing the same microporelliform ooecial structure. The microporelliform ooecium consists of an uncalcified ectooecium and a calcified endooecium separated by a narrow coelomic space in communication with the hypostegal coelom of the distal autozooid, and has been found only in the lepraliomorph families Microporellidae Hincks, 1879, Pacificincolidae Liu \& Liu, 1999, Schizoporellidae Jullien, 1883, Myriaporidae Gray, 1824 and Porinidae d'Orbigny, 1852 (Ostrovsky 2013). Powellitheca gen. nov. cannot be accommodated in any of these families. It lacks the ascopore typical of Microporellidae and the small heterozooid (avicularium or kenozooid) placed between the orifice and the umbo seen in Pacificincolidae. In Schizoporellidae the orifice has well-defined condyles separating a distinct anter from a small sinus, while the orifice in Powellitheca gen. nov. is dimorphic, condyles are faint and a sinus is lacking. An orifice with sinus and condyles also characterises Myriaporidae from which Powellitheca gen. nov. further differs in having multiporous instead of uniporous septula. Porinidae typically have erect colonies, a primary orifice with a well-defined sinus, a well-developed aviculiferous peristome, and a short frontal spiramen. 


\section{Powellitheca gen. nov. \\ urn:1sid:zoobank.org:act:43B95C9D-F5C5-4802-B508-A952DA9020A6}

\section{Type species}

Powellitheca terranovae gen. et sp. nov.

\section{Diagnosis}

Colony encrusting, with zooids arranged in well-defined longitudinal rows. Zooids with convex, lepralioid frontal shield, regularly and evenly perforated. Lateral zooidal communication through small number of multiporous septula in vertical walls. Orifice dimorphic, wider in maternal zooids. Primary orifice with convex proximal rim and small condyles; not cormidial. Suboral umbo and lyrula present or absent; oral spines lacking. Ovicells hyperstomial. Ooecia of the microporelliform type, large, globular, occupying most of the frontal shield of the next distal zooid. Ectooecium uncalcified. Endooecium thick, granular with deep oval and round pits. Avicularia present or absent, uncommon when present.

\section{Etymology}

Named after Neil A. Powell who first described Recent specimens now attributed to this genus in the 'Terra Nova' Collection from the Three Kings Islands area, northern tip of New Zealand.
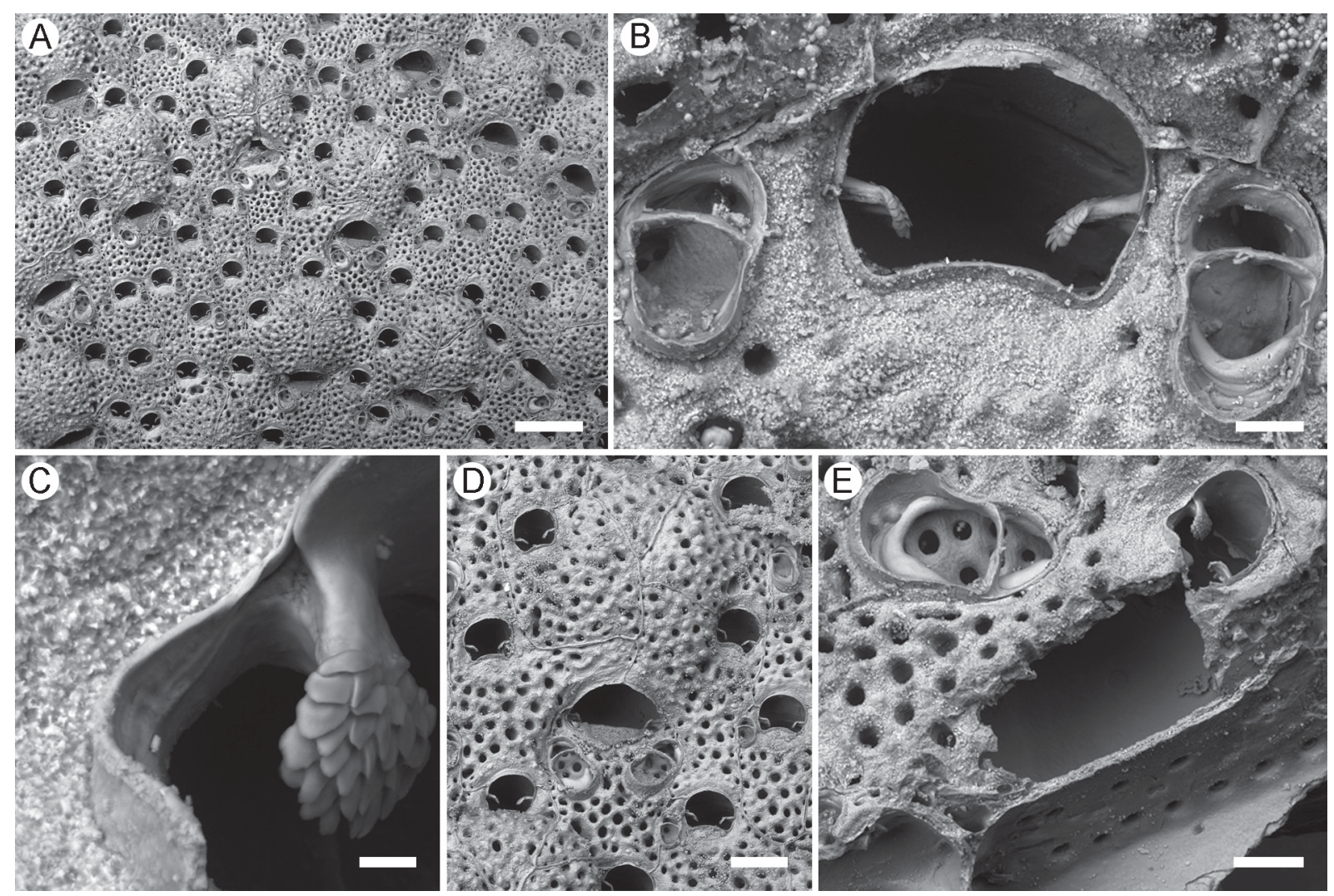

Fig. 1. Emballotheca quadrata (MacGillivray, 1880), NHMUK 1897.5.1.830, Recent, Port Phillip Heads, Victoria, Australia. A. General view of the colony. B. Autozooidal orifice and avicularia. C. Close-up of a condyle with scaled tip. D. Fertile zooid and surrounding autozooids. E. Large, spatulate, frontal avicularium and lateral pore-chamber windows in the vertical walls. Scale bars: $A=500 \mu \mathrm{m} ; \mathrm{B}=40 \mu \mathrm{m}$; $\mathrm{C}=10 \mu \mathrm{m} ; \mathrm{D}=200 \mu \mathrm{m} ; \mathrm{E}=100 \mu \mathrm{m}$. 


\section{Remarks}

The new genus Powellitheca gen. nov. is introduced for three species of cheilostomes from New Zealand, one of which was previously placed in the Australian genus Emballotheca. After comparing these species with a specimen of the type species of Emballotheca, E. quadrata (Fig. 1), it is clear that they differ in several respects, particularly with regard to the morphology of the orifice, ooecium and avicularia. Although both Emballotheca and Powellitheca gen. nov. have enlarged orifices in maternal zooids and a similar orificial shape with a convex proximal lip, Powellitheca gen. nov. lacks the cormidial orifice seen in Emballotheca, as well as the long and robust condyles with very characteristic downwardly directed, scaled tips (Fig. 1B-C). Ovicells in Emballotheca are hyperstomial and cleithral. The ooecium is of the lepralielliform type, large, formed by the next distal zooid and occupying its entire frontal shield. The globular ectooecium is calcified, thick-walled, with numerous oval and round pseudopores, in most cases covered by the secondary calcification formed by the four or five distal and distolateral neighboring zooids and separated by thin raised sutures (Fig. 1A, D). Secondary calcification corresponds structurally to the zooidal frontal shield and bears pseudopores that are coincident in position with those of the ectooecium. The endooecium is thin and uncalcified (A. Ostrovsky, pers. comm. 2016). Although Powellitheca gen. nov. also has hyperstomial ovicells and the ooecium is similarly large and granular, the ooecia are totally different as they have an uncalcified ectooecium and a calcified endooecium typical of the microporelliform type.

Avicularia in the type species of Emballotheca have a complete crossbar and are directed proximally and towards the midline of the autozooid (Fig. 1B, D-E), whereas in Powellitheca gen. nov., when present, they have an incomplete crossbar with short condyles and are distally and outwardly directed. In E. quadrata, avicularia occur constantly paired in female zooids (Fig. 1A, D), but in Powellitheca gen. nov. they are uncommon and less regularly placed. Another difference concerns the arrangement of zooidal communication pores in the lateral walls, with numerous, small, oval pore chamber windows in Emballotheca (Fig. 1E), but only a few large and consequently more distantly spaced multiporous septula in Powellitheca gen. nov.

Powellitheca terranovae gen. et sp. nov. urn:1sid:zoobank.org:act:F8CC3594-F2CB-4E98-945E-800B0C2A460C

Figs $2 \mathrm{~A}-\mathrm{F}, 7$, Table 1

Emballotheca waipukurensis - Powell 1967: 336, fig. 87. — Gordon 1989: 36, pl. 17, figs E-F. Gordon et al. 2009: 291.

\section{Diagnosis}

Colony encrusting. Zooids rectangular, arranged in well-defined rows. Frontal shield convex, regularly and evenly perforated, apart from a narrow peristomial area lacking pores, granular. Small, frontal, multiporous septula at the distolateral and proximolateral corners of the zooids. Lateral zooidal communications through multiporous septula visible on the vertical walls. Orifice with a convex proximal lip and two small, lateroproximally placed condyles, bearing an anvil-shaped median lyrula directed downwards and not visible in frontal view. Oral spines absent. Ooecium large, globular, occupying most of the frontal shield of the next distal zooid, porous and granular with the same texture as the frontal shield. Avicularia uncommon, single or paired, with short condyles and tapered rounded rostrum distolaterally directed.

\section{Etymology}

Named after the 'Terra Nova' Expedition, the source of several specimens of this species described initially by Powell (1967). 


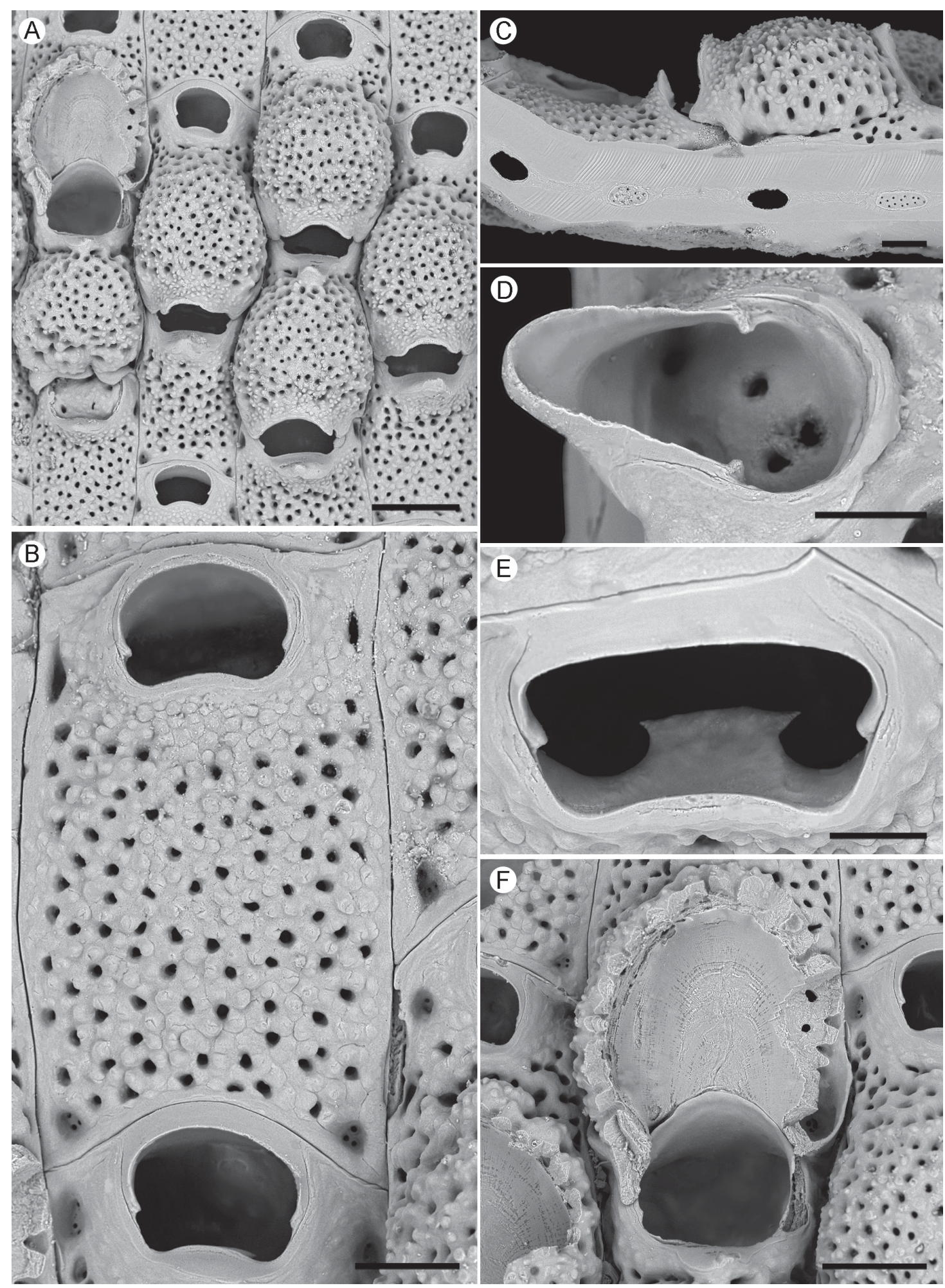

Fig. 2. Powellitheca terranovae gen. et sp. nov. NIWA 98983, Recent, Stephens Hole, NZOI Station Q686, New Zealand. A. Group of fertile zooids and autozooids. B. Close-up of an autozooid showing frontal, multiporous septula on the distolateral corners. C. Lateral, multiporous septula on the vertical walls of a maternal zooid. Note also the prominent, suboral umbo. D. Avicularium. E. Tilted view of an autozooidal orifice to show the anvil-shaped, downwardly directed lyrula. F. Orifice of a maternal zooid and incomplete ooecium. Scale bars: $\mathrm{A}=250 \mu \mathrm{m} ; \mathrm{B}-\mathrm{C}=100 \mu \mathrm{m} ; \mathrm{D}-\mathrm{E}=50 \mu \mathrm{m} ; \mathrm{F}=150 \mu \mathrm{m}$. 
Table 1. Measurements in microns of Powellitheca terranovae gen. et sp. nov.

\begin{tabular}{cccccc}
\hline & N (zooids, colonies) & Mean & SD & Min & Max \\
\hline ZL & 20,1 & 636 & \pm 80 & 522 & 824 \\
ZW & 20,1 & 315 & \pm 49 & 233 & 410 \\
OL & 20,1 & 126 & \pm 12 & 111 & 156 \\
OW & 20,1 & 167 & \pm 8 & 158 & 189 \\
OL* & 13,1 & 223 & \pm 18 & 200 & 267 \\
OW* & 10,1 & 242 & \pm 24 & 179 & 264 \\
OvL & 9,1 & 489 & \pm 31 & 444 & 544 \\
OvW & 16,1 & 432 & \pm 25 & 400 & 468 \\
AvL & 4,1 & 186 & \pm 10 & 177 & 198 \\
AvW & 4,1 & 94 & \pm 12 & 59 & 91 \\
\hline
\end{tabular}

\section{Material examined}

\section{Holotype}

NEW ZEALAND: NIWA 98983, Recent, 2 Dec. 1981, Stephens Hole, Cook Strait, NZOI Station Q686, $40^{\circ} 41.3^{\prime} \mathrm{S}, 174^{\circ} 03.8^{\prime} \mathrm{E}, 205 \mathrm{~m}$.

\section{Description}

Colony encrusting, multiserial, unilaminar; colour yellow. Ancestrula not observed. Zooids arranged in well-defined rows (Fig. 2A), distinct, boundaries marked by very narrow furrows, quadrate to rectangular generally with squared corners, straight or curved zooidal lateral boundaries, longer than broad (mean $\mathrm{L} / \mathrm{W}=2.02$ ). Polypides with 19 tentacles. Frontal shield lepralioid, convex, granular, regularly and evenly perforated by $50-80$ small, circular or slit-like pseudopores about $15-20 \mu \mathrm{m}$ in diameter (Fig. 2B). Small, rounded triangular, multiporous frontal septula, bearing three or four inconspicuous pores, about 5-6 $\mu \mathrm{m}$ in diameter, placed at distolateral and proximolateral zooidal corners (Fig. 2B), often hidden in ovicellate zooids owing to a different surface topography in that area. Orifice placed distally, generally broader than long, with the proximal rim gently convex and two tiny condyles placed proximal to the mid-lateral position; an imperforate, granular, slightly raised peristomial rim surrounding the orifice (Fig. 2E). An anvil-shaped lyrula, placed medially, 60-90 $\mu \mathrm{m}$ broad, occupies about half of orifice width, directed downwards, vertically or distovertically, and not visible in frontal view (Fig. 2E). Oral spines and suboral umbo absent. Ovicells hyperstomial. Ooecia globular, large, occupying almost the entire frontal shield length of the next distal zooid forming the ooecium. Ectooecium uncalcified. Endooecium thick, granular like the frontal shield but with a finer granulation, with deep oval and round pits (11-20 $\mu \mathrm{m}$ in diameter) and with a proximal, granular, imperforate band and a narrow, smooth, frontal rim, slightly upturned (Fig. 2A, C, F). Primary orifice of fertile zooids larger than that of autozooids, rounded quadrangular, slightly broader than long with a smooth, stout suboral umbo (Fig. 2A, C, F); secondary orifice slit-like (Fig. 2A). Avicularia uncommon, adventitious, usually single, rarely paired, lateral to the orifice, on or adjacent to ovicellate zooids, distolaterally directed, with short condyles, no calcified crossbar, rounded tapered rostrum (Fig. 2D). Oval, multiporous (at least 14 pores) septula in lateral vertical walls, about $95-120 \mu \mathrm{m}$ long by $45-55 \mu \mathrm{m}$ wide (Fig. 2C). Intramural, reparative budding observed (Fig. 2A).

\section{Remarks}

Originally included in the 'Emballotheca waipukurensis group' together with the Plio-Pleistocene $P$. waipukurensis comb. nov. (see description below), the Recent specimens now assigned to P. terranovae 
gen. et sp. nov. differ from true $P$. waipukurensis comb. nov. in having an anvil-shaped median lyrula that is difficult to observe in frontal view because it is directed either vertically downwards or only slightly distally angled. Further differences are the lack of a suboral umbo in the non-ovicellate zooids of $P$. terranovae gen. et sp. nov., a feature that in this species is restricted to the female zooids, and the different shape of the avicularium rostrum, which is spatulate in $P$. waipukurensis comb. nov. but distally tapered and rounded in P. terranovae gen. et sp. nov. They also differ in the size of the zooids, orifice and ooecia, which are slightly larger in P. terranovae gen. et sp. nov.

\section{Distribution}

This species is known from the Cook Strait area and the Three King Islands, from 75 to $205 \mathrm{~m}$ depth.

Powellitheca labiosa gen. et sp. nov. urn:1sid:zoobank.org:act:081F29FC-4C82-4F0D-A537-1AC61EE8E93B

Fig. 3A-F, Table 2

\section{Diagnosis}

Colony encrusting. Zooids polygonal, arranged in well-defined rows. Frontal shield markedly convex, regularly and evenly perforated, smooth. Small, frontal, multiporous septula at the distolateral and proximolateral zooidal corner. Lateral zooidal communications through small multiporous septula visible on the vertical walls. Orifice with a weakly convex proximal lip and two small latero-proximally placed condyles; lyrula and oral spines absent. Primary orifice hidden by a flat, imperforate, finely granular, projection of the peristome present in both ovicelled zooids and autozooids. Ooecium large, globular, occupying most of the frontal shield of the next distal zooid, porous and granular. Avicularia absent.

\section{Etymology}

The name of the species derives from the Latin adjective labiosus, - $a$, -um meaning 'with a large lip', and refers to the flat, labrum-like projection of the peristome covering the primary orifice.

\section{Material examined}

\section{Holotype}

NEW ZEALAND: NIWA 11828, Recent, 29 Mar. 2011, South Maria ridge, NE of Three King Islands,

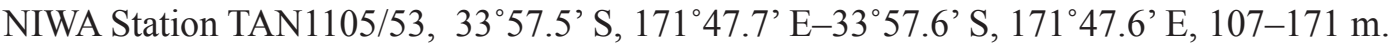

\section{Paratypes}

NEW ZEALAND: NIWA 98229, 98230, same data as for holotype.

\section{Description}

Colony encrusting, multiserial, unilaminar (Fig. 3A, D). Maximum colony size about $4 \mathrm{~mm}$ long by 2-4 mm wide, fan-shaped. Ancestrula not observed. Zooids arranged in well-defined rows, distinct, boundaries marked by thin furrows, polygonal, longer than broad (mean $\mathrm{L} / \mathrm{W}=1.36$ ). Frontal shield lepralioid, markedly convex, smooth, regularly and evenly perforated by 30-40 small, circular pseudopores, about $20-35 \mu \mathrm{m}$ in diameter, sometimes funnel-shaped (Fig. 3C). Small, multiporous frontal septula, bearing three very small (about $5 \mu \mathrm{m}$ wide) semicircular pores, placed at distolateral and proximolateral zooidal corners (Fig. 3C) in both ovicellate and non-ovicellate zooids. Orifice of autozooids placed distally, generally broader than long, with the proximal lip weakly convex and two small, proximolaterally placed condyles (Fig. 3B). A large, flat, imperforate, finely granular, projection of the peristome hides the orifice in both autozooids and maternal zooids (Fig. 3A); lyrula and oral spines absent (Fig. 3B). Ovicells hyperstomial. Ooecia globular, large, occupying almost the entire frontal 

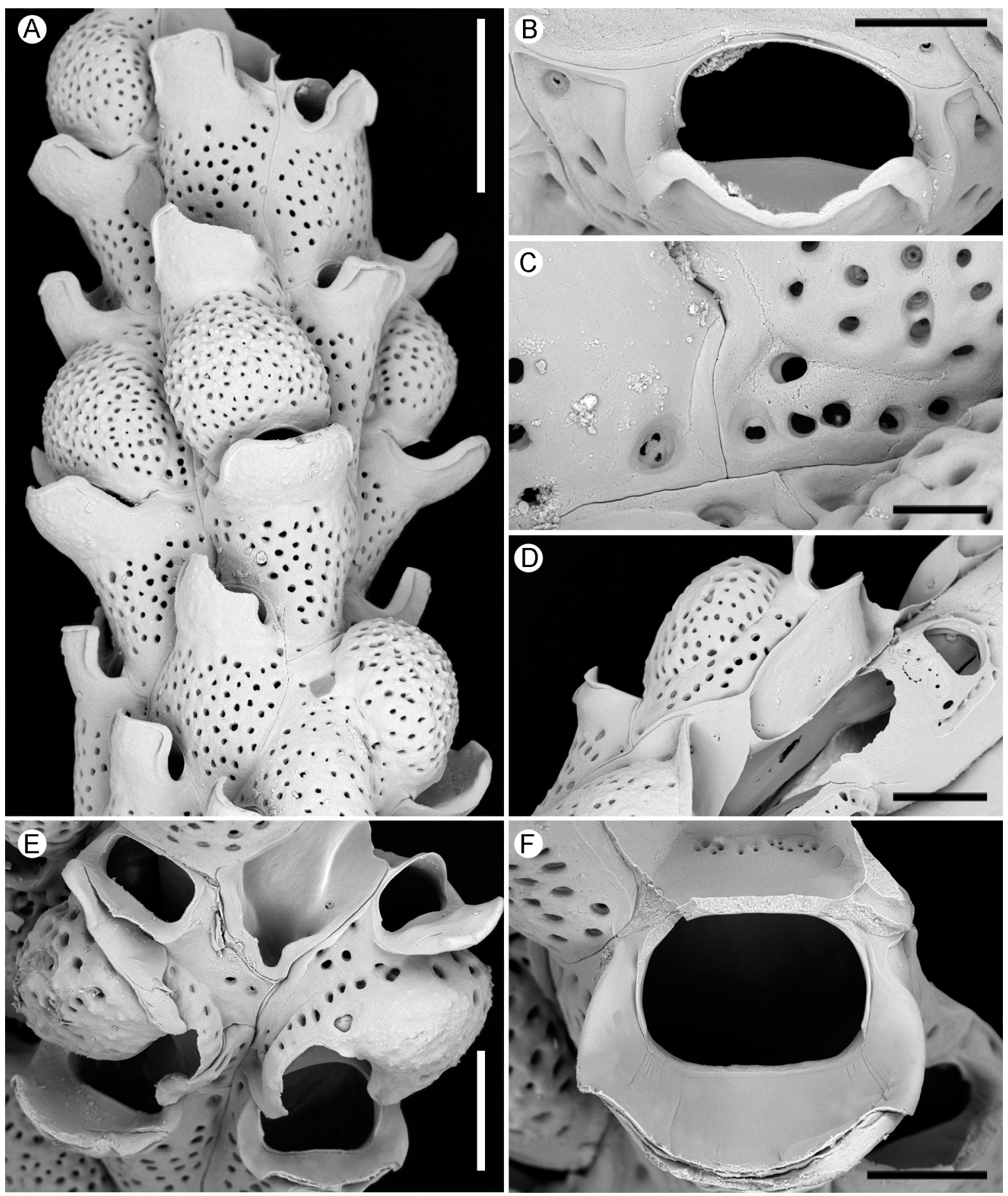

Fig. 3. Powellitheca labiosa gen. et sp. nov. NIWA 98320 (A-C, E-F), 98229 (D), Recent, Three King Islands, New Zealand. A. Group of fertile zooids and autozooids. B. Tilted view of the primary orifice of an autozooid. Note the lack of a lyrula. C. Close-up of the frontal, multiporous septula on the distolateral corners and the funnel-shaped pseudopores on the frontal shield. D. Lateral, multiporous septula on the zooidal vertical walls. $\mathbf{E}-\mathbf{F}$. Tilted view of the orifice of fertile zooids. Scale bars: $\mathrm{A}=500 \mu \mathrm{m}$; $\mathrm{B}-\mathrm{C}=100 \mu \mathrm{m} ; \mathrm{D}=200 \mu \mathrm{m} ; \mathrm{E}=250 \mu \mathrm{m} ; \mathrm{F}=150 \mu \mathrm{m}$. 
Table 2. Measurements in microns of Powellitheca labiosa gen. et sp. nov.

\begin{tabular}{cccccc}
\hline & N (zooids, colonies) & Mean & SD & Min & Max \\
\hline ZL & 20,4 & 594 & \pm 53 & 500 & 722 \\
ZW & 20,4 & 438 & \pm 112 & 311 & 678 \\
OL & 10,4 & 124 & \pm 16 & 103 & 158 \\
OW & 17,4 & 218 & \pm 24 & 170 & 256 \\
OL $^{*}$ & 3,2 & 218 & \pm 17 & 200 & 234 \\
OW $^{*}$ & 4,2 & 269 & \pm 21 & 249 & 289 \\
OvL & 8,2 & 473 & \pm 64 & 333 & 533 \\
OvW & 8,2 & 461 & \pm 24 & 443 & 500 \\
\hline
\end{tabular}

shield of the next distal zooid forming the ooecium. Ectooecium uncalcified. Endooecium granular with deep oval and round pits that are smaller $(15-20 \mu \mathrm{m}$ in diameter) and more numerous than pseudopores of the frontal shield (Fig. 3A). Primary orifice of fertile zooids larger than that of autozooids, rounded quadrangular, slightly broader than long (Fig. 3E-F). Avicularia absent. Multiporous septula small, about $30-35 \mu \mathrm{m}$ long by $20-25 \mu \mathrm{m}$ wide, very distant to each other, bearing two to four tiny pores visible in lateral vertical walls (Fig. 3D).

\section{Remarks}

This species is similar to Powellitheca terranovae gen. et sp. nov. and P. waipukurensis comb. nov. (see description below) in having a convex, porous frontal shield with small, multiporous frontal septula at the distolateral and proximolateral zooidal corners (these cannot be seen in studied fossils of P. waipukurensis comb. nov.), large, globular, porous and granular ooecia, dimorphic orifices with a convex proximal lip and tiny proximolateral condyles, and oval, multiporous septula on the vertical lateral walls. It differs from P. terranovae gen. et sp. nov. and P. waipukurensis comb. nov. (see description below) in having a well-developed, labrum-like projection of the peristome, and also in having a smooth, non-granular frontal shield with larger pseudopores. The septula in vertical walls are fewer and much smaller with a reduced number of pores, circular in P. terranovae gen. et sp. nov., but semicircular in P. labiosa gen. et sp. nov. In addition, P. labiosa gen. et sp. nov. lacks a lyrula and avicularia.

\section{Distribution}

This species is known only from the South Maria ridge, NE of the Three King Islands.

Powellitheca waipukurensis (Waters, 1887) comb. nov.

Figs 4, 5A-D, 6, Table 3

Monoporella waipukurensis Waters, 1887: 50, pl. 6, fig. 11.

Hippoporina? waipukurensis - Brown 1952: 272, figs 203-204.

Emballotheca waipukurensis - Gordon et al. 2009: 296. — Rust \& Gordon 2011: 156.

\section{Material examined}

\section{Lectotype}

NEW ZEALAND: NHMUK D32522, Mangapanian, ?Pliocene, Hawkes Bay, Waipukurau Gorge.

\section{Additional figured material}

NEW ZEALAND: NHMUK BZ 7744 and BZ 7745, Nukumaruan, Pleistocene, Nukumaru Limestone, Waiinu Beach; NHMUK D36986, same details as lectotype. 
Other material

NEW ZEALAND: NIWA 98228, 15 colonies from Hatuma Quarry, Waipukurau.

\section{Description}

Colony large, encrusting, multiserial, unilaminar (Figs 4, 5A, 6A). Ancestrula minimally calcified, comprising a thin rim of granular cryptocystal calcification with the outline shaped as a matryoshka doll, about $250-450 \mu \mathrm{m}$ long by $250-355 \mu \mathrm{m}$ wide, budding one distal and two distolateral zooids (Fig. 6D-E). First three budded zooids smaller than later ones, about 230-360 $\mu \mathrm{m}$ long by 240-300 $\mu \mathrm{m}$ wide, hexagonal (Fig. 6D). Zooids developed from ancestrular buds are irregularly polygonal and

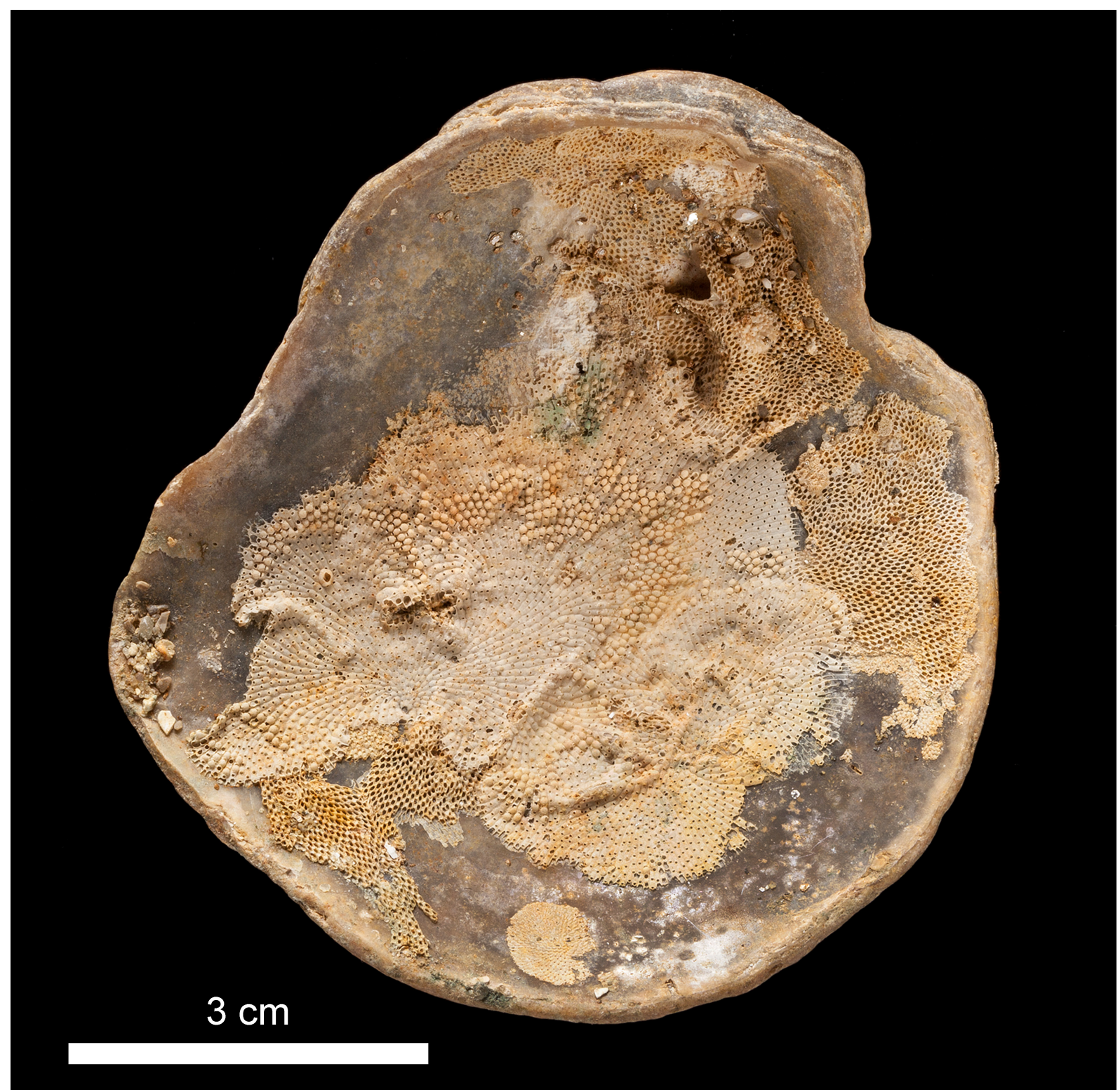

Fig. 4. Powellitheca waipukurensis (Waters, 1887) comb. nov. NHMUK BZ 7744, Nukumaruan, Pleistocene, Nukumaru Limestone, Waiinu Beach. Two colonies of $P$. waipukurensis encrusting a bivalve shell, competing with other bryozoan species for space. Note the band of fertile zooids with large, globular ovicells. 
angled at $90^{\circ}$ to $180^{\circ}$ to encircle the ancestrula (Fig. 6D). Later autozooids arranged in well-defined rows, distinct, boundaries marked by very narrow furrows, quadrate to rectangular, generally with squared corners, longer than broad, with a highly variable length/width ratio (mean $\mathrm{L} / \mathrm{W}=2.23$ ), some appearing squat and others slender (Figs 5, 6A-B). Frontal shield lepralioid, slightly convex, granular, regularly and evenly perforated by $40-50$ small, circular pores about $10-15 \mu \mathrm{m}$ in diameter (Fig. 6A-C). Frontal septula not distinguishable, probably because of obliteration by the growth of diagenetic cement. Orifice placed distally, generally broader than long, with the proximal lip gently convex and two tiny condyles placed proximal to the midlateral position (Fig. 6F); an imperforate, smooth, scarcely raised peristomial rim lateral and distolateral to the orifice, terminating in a flat, suboral umbo, palette-shaped, often broken and leaving an oval depression (Figs 5C-D, 6F). Lyrula and oral spines absent (Fig. 6G). Ovicells hyperstomial. Ooecia globular, large, occupying almost the entire frontal shield of the next distal zooid forming the ooecium. Ectooecium membranous. Endooecium calcified, tubercular like the frontal shield, with deep pits and tubercles radially aligned in alternating ridges and furrows, the frontal rim imperforate and smooth, slightly upturned (Figs 5A-C, 6C). Primary orifice of fertile zooids larger than that of autozooids, rounded quadrangular, about as long as wide; secondary orifice slit-like with a tongue-shaped, suboral umbo (Figs 5A-C, 6C). Avicularia uncommon, adventitious, placed lateral to the orifice or at zooid midlength, usually single, rarely paired, when paired one smaller, semielliptical or 8-shaped with a spatulate, rounded rostrum, distolaterally directed (Figs 5C, 6C, F), no crossbar. Kenozooids budded at junctions between colonies growing on same substratum, similar to autozooids
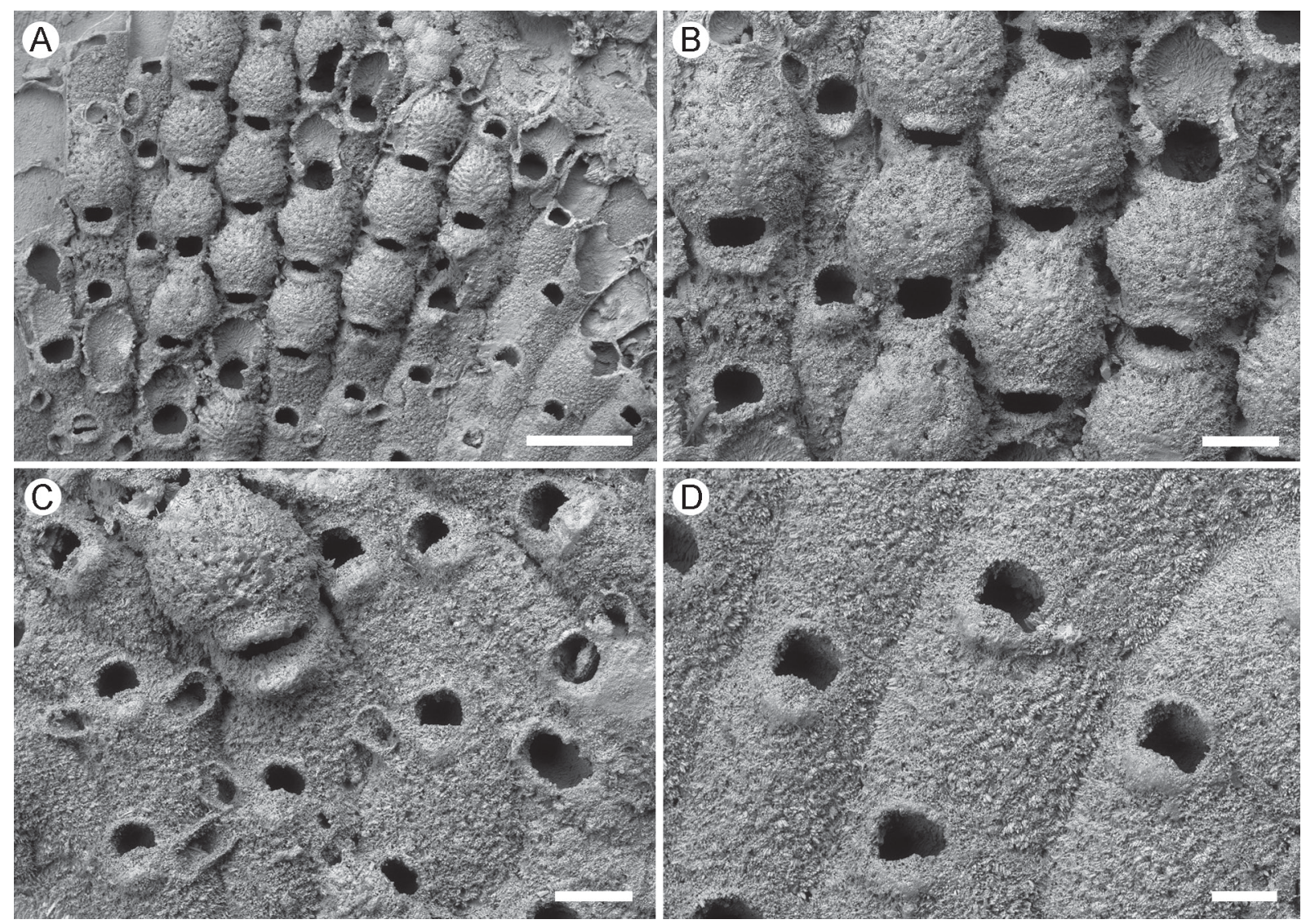

Fig. 5. Powellitheca waipukurensis (Waters, 1887) comb. nov. Specimen figured by Brown (1952: fig. 203), NHMUK D36986, Mangapanian, Early Pliocene, Hawkes Bay, Waipukurau Gorge. A. General view of the colony. B. Group of autozooids and fertile zooids showing the dimorphic orifices. C. Group of zooids with avicularia. D. Autozooids. Scale bars: A $=500 \mu \mathrm{m}$; B-C $=200 \mu \mathrm{m}$; D $=100 \mu \mathrm{m}$. 

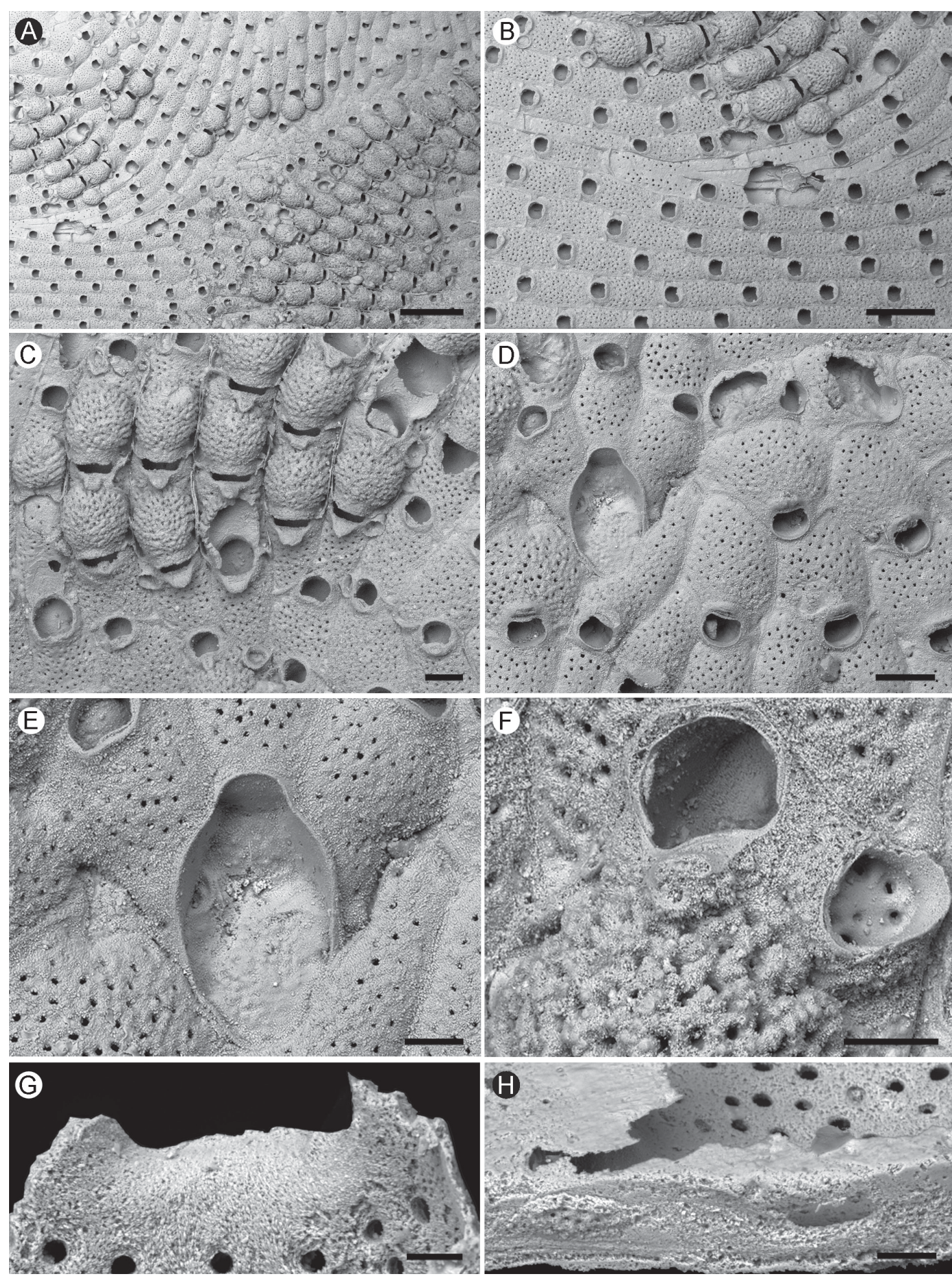

Fig. 6. Powellitheca waipukurensis (Waters, 1887) comb. nov. Nukumaruan, Pleistocene, Nukumaru Limestone, Waiinu Beach. A-F. NHMUK BZ 7744. A. General view of two colonies encrusting a bivalve shell. B. Fusion of the two colonies shown in A and formation of kenozooids along the encountering edge. C. Group of fertile zooids and autozooids. D. Ancestrula and early ontogeny. E. Close-up of the minimally calcified ancestrula. F. Autozooidal orifice and avicularium. - G-H. NHMUK BZ 7745. G. Internal view of the proximal, convex, orificial rim lacking a lyrula. H. Multiporous septula on the zooidal vertical walls. Scale bars: A $=1 \mathrm{~mm} ; \mathrm{B}=500 \mu \mathrm{m} ; \mathrm{C}-\mathrm{D}=200 \mu \mathrm{m} ; \mathrm{E}-\mathrm{F}=100 \mu \mathrm{m} ; \mathrm{G}-\mathrm{H}=20 \mu \mathrm{m}$. 
Table 3. Measurements in microns of Powellitheca waipukurensis (Waters, 1887) comb. nov.

\begin{tabular}{cccccc}
\hline & N (zooids, colonies) & Mean & SD & Min & Max \\
\hline ZL & 22,4 & 562 & \pm 50 & 469 & 679 \\
ZW & 22,4 & 248 & \pm 49 & 182 & 367 \\
OL & 22,4 & 113 & \pm 11 & 94 & 139 \\
OW & 22,4 & 142 & \pm 20 & 114 & 182 \\
OL $^{*}$ & 12,4 & 203 & \pm 19 & 177 & 203 \\
OW $^{*}$ & 12,4 & 211 & \pm 14 & 190 & 211 \\
OvL & 40,4 & 406 & \pm 37 & 339 & 476 \\
OvW & 40,4 & 354 & \pm 38 & 258 & 429 \\
AvL & 12,4 & 149 & \pm 17 & 119 & 177 \\
AvW & 12,4 & 102 & \pm 12 & 84 & 130 \\
\hline
\end{tabular}

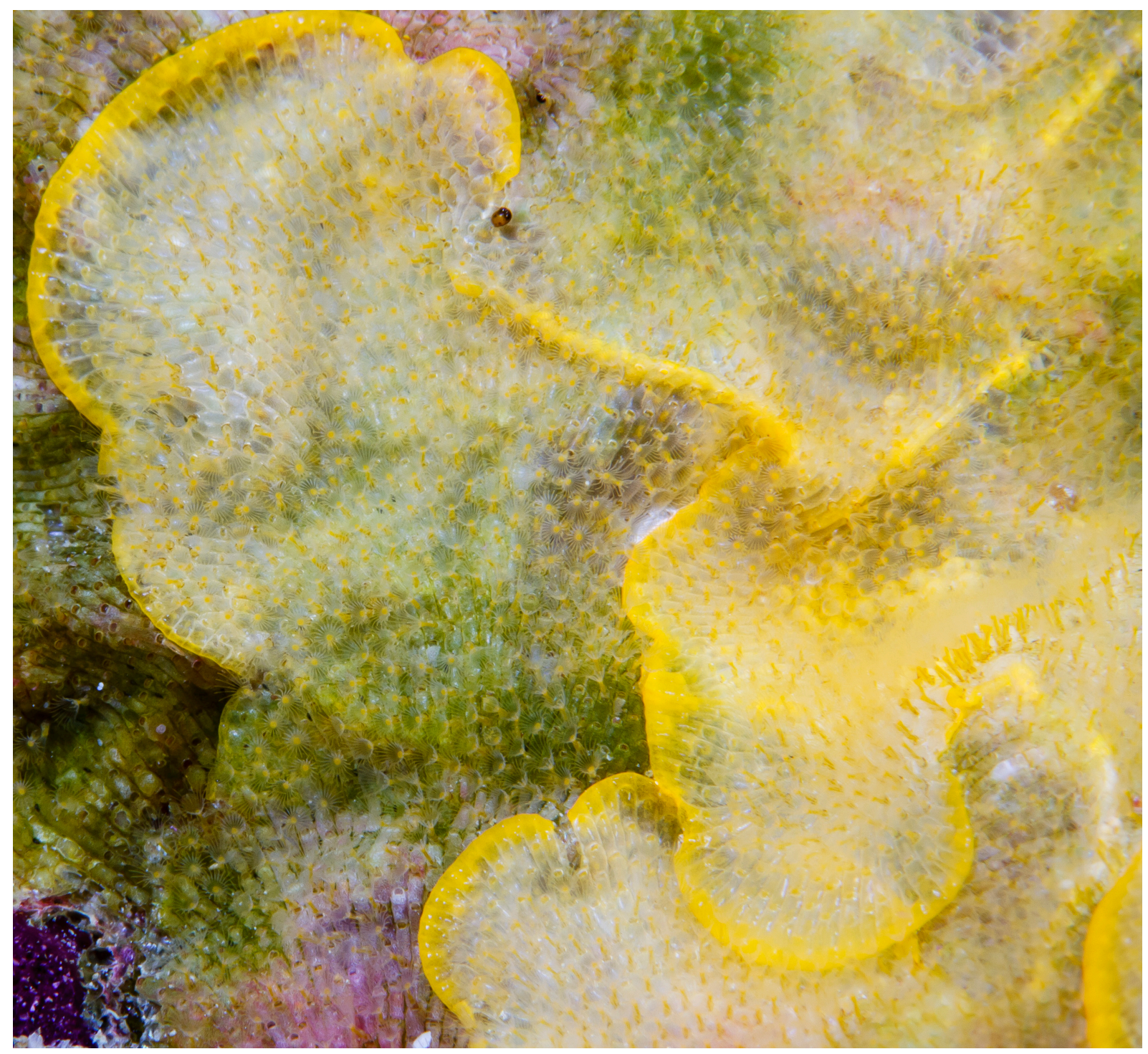

Fig. 7. Powellitheca terranovae gen. et sp. nov. Underwater photograph taken by Dr. Vincent Zintzen (Department of Conservation, NZ) at the Poor Knights Islands, off the NE coast of North Island, north of Auckland, New Zealand. Note the band of yellow pigment at the colony's growing edges and the 19 yellow tentacles of the autozooids. 
in size and in the appearance of the frontal shield but lacking apertures (Fig. 6B). Oval, multiporous (at least six pores) septula visible on vertical walls (Fig. $6 \mathrm{H}$ ), about $40 \mu \mathrm{m}$ long by $20 \mu \mathrm{m}$ wide. Intramural, reparative budding also observed (Fig. 6C).

\section{Remarks}

Brown (1952: 272, fig. 204) chose NHMUK D32522 from Waipukurau Gorge as the lectotype of this species. This specimen forms part of the T. Hincks Collection and is accommodated in a cavity slide that was labelled "Monoporella waipukurensis on Heteropora [sic]" by Eliza Jelly. Jelly traded bryozoans extensively in the late $19^{\text {th }}$ century (Torrens \& Winston 2002: 307-308) and the supposition must be that this particular specimen was used by Waters when describing his new species, then passed on to Jelly who in turn gave it to Hincks. Brown figured (fig. 203) a fertile specimen (D36986; Fig. 5) from the same locality and collection to provide details of ooecia, which are lacking in both the lectotype and the Waters' specimen from Napier housed in the Manchester Museum. Brown (1952, p. 274) questioned the status of the Manchester Museum specimen, describing it as a slide labelled "Monoporella waipukurensis" by Waters and referring to it as a "?original syntype". As this specimen lacks ovicells, he considered that it was not the specimen figured by Waters (1887, pl. 6, fig. 11), which does have ovicells.

\section{Distribution}

This species has been found in the Mangapanian Te Aute Limestone (Pliocene, 3.1 Ma) of Waipukurau Gorge and nearby Hatuma Quarry, Hawkes Bay, and in the Nukumaruan (early Pleistocene) Nukumaru Limestone ( 2.3-2.0 Ma) and Nukumaru Brown Sand ( 2.0-1.9 Ma) units of Nukumaru and Waiinu beaches, Wanganui Basin, and Nukumaruan at Petane (trigonometrical station), just north of Napier, Hawkes Bay, New Zealand.

\section{Discussion}

The continental shelf around New Zealand supports a rich bryozoan fauna estimated to number almost 1000 species (Gordon et al. 2009). Evidence from the fossil record suggests that high diversities of bryozoans have characterized this region for at least 50 million years (e.g., Gordon \& Taylor 2015).

Current research focusing on Plio-Pleistocene bryozoans from the Wanganui Basin has prompted the re-evaluation of a common cheilostome usually known as Emballotheca waipukurensis (Waters, 1887), which was originally described from Waipukurau Gorge in Hawkes Bay. Comparison of this species with the Australian type species of Emballotheca, E. quadrata (MacGillivray, 1880), reveals major differences in skeletal morphology. In particular, the autozooidal orifice in E. quadrata is cormidial, while the ooecium is of the lepralielliform type, with an uncalcified endooecium and a calcified ectooecium, covered by the sutured secondary calcification formed by several zooids distal and distolateral of the fertile zooid. These features contrast with the non-cormidial autozooidal orifice and the microporelliform ooecial structure of the New Zealand species. Restudy of Recent material from New Zealand previously identified as Emballotheca waipukurensis shows that it too differs from the Australian type species of Emballotheca and, although close to the fossils from New Zealand, differs in several respects, warranting its recognition as a new species. Accordingly, a new genus, Powellitheca gen. nov., is proposed for the fossil and Recent New Zealand species previously assigned to Emballotheca. Because of the future possibility of obtaining molecular sequence data from Recent Powellitheca gen. nov. and therefore placing it in a broader phylogenetic context, $P$. terranovae gen. et sp. nov. is chosen as the type species of this new genus in preference to the fossil species $P$. waipukurensis comb. nov. Another, rarer Recent species of Powellitheca gen. nov. is also recognized, P. labiosa gen. et sp. nov.

The known distribution of Powellitheca gen. nov. is limited to the North Island of New Zealand and includes one fossil and two living species. The geologically oldest occurrence is of $P$. waipukurensis 
comb. nov., which dates back to the Pliocene of Hawkes Bay. This species is common in the Wanganui Basin until the early Pleistocene, and is a component of a rich and abundant encrusting bryozoan fauna associated with Ostrea association and Paphies association palaeocommunity shellbeds (Rust \& Gordon 2011). These shellbeds are interpreted as deposited mainly in shoreface and inner shelf environments. In contrast, the two Recent species $P$. terranovae gen. et sp. nov. and P. labiosa gen. et sp. nov. are found in deeper water, from 75 to $205 \mathrm{~m}$. The first of these species has a broad distribution, from Cook Strait to the Three King Islands at the northern tip of New Zealand, while the second species is currently known only from Three King Islands.

\section{Acknowledgements}

We thank the Curator of the Recent Bryozoan Collection Mary Spencer Jones (NHMUK) and the Assistant Collections Manager Diana Macpherson (NIWA), respectively, for making available specimens of Emballotheca quadrata and Recent Powellitheca gen. nov. for study, and Consuelo Sendino (NHMUK) for curating the fossil material. Comments from Andrey Ostrovsky (Saint Petersburg State University and University of Vienna), Oscar Reverter-Gil (University of Santiago) and an anonymous reviewer helped to improve the originally submitted manuscript. Specimens of P. labiosa gen. et sp. nov. were collected as part of the Biogenic Habitats on the Continental Shelf project (voyages TAN1105 \& TAN1108), funded by New Zealand Ministry of Fisheries (Biogenic Habitats: ZBD200801), New Zealand Foundation for Research, Science and Technology (CCM: CO1X0907), NIWA Capability Fund (CF111358), and Oceans Survey 20/20 R/V Tangaroa days funded by Land Information New Zealand.

\section{References}

Brown D.A. 1952. The Tertiary Cheilostomatous Polyzoa of New Zealand. Trustees of the British Museum, London.

Harmer S.F. 1926. The Polyzoa of the Siboga Expedition, 2. Cheilostomata Anasca. Siboga Expedition Reports 28b: 183-501.

Gordon D.P. 1989. The marine fauna of New Zealand: Bryozoa: Gymnolaemata (Cheilostomida Ascophorina) from the western South Island continental shelf and slope. New Zealand Oceanographic Institute Memoir 97, New Zealand Oceanographic Institute, Wellington.

Gordon D.P. \& Taylor P.D. 2015. Bryozoa of the Early Eocene Tumaio Limestone, Chatham Island, New Zealand. Journal of Systematic Palaeontology 13: 983-1070. http://dx.doi.org/10.1080/14772019 $\underline{.2014 .991905}$

Gordon D.P., Taylor P.D. \& Bigey F.P. 2009. Phylum Bryozoa - moss animals, sea mats, lace corals. In: Gordon D.P. (ed.) New Zealand Inventory of Biodiversity. Volume One. Kingdom Animalia: Radiata, Lophotrochozoa, Deuterostomia: 271-297. Canterbury University Press, Christchurch.

Ostrovsky A.N. 2013. Evolution of sexual reproduction in marine invertebrates: examples of gymnolaemate bryozoans. Springer Verlag, Berlin \& New York. http://dx.doi.org/10.1007/978-94-007-7146-8

Powell N.A. 1967. Polyzoa (Bryozoa) - Ascophora - from north New Zealand. Discovery Reports 34: 199-393.

Rust S. \& Gordon D.P. 2011. Plio-Pleistocene bryozoan faunas of the Wanganui Basin, New Zealand: stratigraphic distribution and diversity. New Zealand Journal of Geology and Geophysics 54 (2): 151165. http://dx.doi.org/10.1080/00288306.2010.514928

Torrens H.S. \& Winston J.E. 2002. Eliza Catherine Jelly (28 ${ }^{\text {th }}$ September $1829-3^{\text {rd }}$ November 1914): pioneer female bryozoologist. In: Wyse Jackson P.N. \& Spencer Jones M.E. (eds) Annals of Bryozoology: 
aspects of the history of research on bryozoans: 299-325. International Bryozoology Association, Dublin.

Waters A.W. 1887. On Tertiary chilostomatous Bryozoa from New Zealand. Quarterly Journal of the Geological Society 43: 40-72. http://dx.doi.org/10.1144/GSL.JGS.1887.043.01-04.08

Manuscript received: 17 December 2015

Manuscript accepted: 9 March 2016

Published on: 23 June 2016

Topic editor: Christian de Muizon

Desk editor: Kristiaan Hoedemakers

Printed versions of all papers are also deposited in the libraries of the institutes that are members of the EJT consortium: Muséum national d'Histoire naturelle, Paris, France; Botanic Garden Meise, Belgium; Royal Museum for Central Africa, Tervuren, Belgium; Natural History Museum, London, United Kingdom; Royal Belgian Institute of Natural Sciences, Brussels, Belgium; Natural History Museum of Denmark, Copenhagen, Denmark; Naturalis Biodiversity Center, Leiden, the Netherlands. 